\title{
UPAYA PENINGKATAN PRESTASI BELAJAR IPS MELALUI PENDEKATAN LEARNING COMMUNITY MATERI MENGEMBANGKAN EKONOMI KREATIF BEDASARKAN POTENSI WILAYAH PADA SISWA KELAS IX D MTS NEGERI 3 TRENGGALEK TAHUN PELAJARAN 2019/2020
}

\author{
IMAM MA'SUM \\ MTs Negeri 3 Trenggalek \\ E-mail : imammasum996@gmail.com
}

\begin{abstract}
ABSTRAK
Penelitian tindakan kelas ini dilatar belakangi oleh kondisi belajar siswa pada mata pelajaran IPS yang tidak fokus menerima materi, siswa cenderung ngobrol. Hal ini berdampak terhadap hasil ulangan harian pertama siswa yang tidak dapat mencapai KKM. Tujuan penelitian ini adalah untuk meningkatkan prestasi belajar siswa khusunya di kelas IX D MTs Negeri 3 Trenggalek.Penelitian ini menggunakan metode penelitian tindakan kelas (PTK) sebanyak dua siklus. Setiap putaran terdiri dari empat tahap yaitu: perencanaan, pelaksanaan, pengamatan dan refleksi. Prosedur yang digunakan dalam mengumpulkan data antara lain: angket, observasi, wawancara. Analisis data pada penelitian ini mencangkup reduksi data, penyajian data, penarikan kesimpulan. Indikator keberhasilan dalam penelitian ini apabila penguasaan materi peserta didik mencapai KKM70.Kesimpulan penelitian iniadalah sebagai berikut: 1) Hasil belajar pada siklus I terdapat kenaikan prestasi belajar berupa rata-rata kelas menjadi 63,33 dan hanya $50 \%$ siswa memperoleh nilai tuntas. Nilai terendah adalah 50 dan nilai tertinggi adalah 90. 2) Hasil belajar pada siklus II terdapat kenaikan prestasi belajar berupa rata-rata kelas menjadi 78,80 dan sebanyak $88 \%$ siswa memperoleh nilai tuntas. Nilai terendah adalah 65 dan nilai tertinggi adalah 90.3).
\end{abstract}

Kata Kunci: Prestasi Belajar, Learning Community

\section{PENDAHULUAN}

Secara praktis, guru adalah ujung tombak dalam pembelajaran. Strategi dan manajemen guru untuk mengatasi masalah pembelajaran sangat dibutuhkan dalam upaya meningkatkan kualitas pembelajaran. Pelaksanaan pembelajaran di dalam kelas merupakan salah satu tugas utama guru, dan pembelajaran dapat diartikan sebagai kegiatan yang ditujukan untuk membelajarkan siswa. Dalam proses pembelajaran masih sering ditemui adanya kecenderungan meminimalkan keterlibatan siswa. Dominasi guru dalam proses pembelajaran menyebabkan kecenderungan siswa lebih bersifat pasif sehingga mereka lebih banyak menunggu sajian guru dari pada mencari dan menemukan sendiri pengetahuan, ketrampilan atau sikap yang merekabutuhkan.Dalam implementasi materi, menemukan IPS lebih menekankan aspek pengetahuan, berpusat pada guru, mengarahkan bahan berupa informasi yang tidak mengembangkan berpikir nilai serta hanya membentuk budaya menghafal dan bukan berpikir kritis. Dalam pelaksanaan menilai pembelajaran IPS sangat menjemukan karena penyajiannya bersifat monoton dan ekspositoris sehingga siswa kurang antusias dan mengakibatkan pelajaran kurang menarik padahal guru IPS wajib berusaha secara optimum merebut minat siswa karena minat merupakan modal utama untuk keberhasilan pembelajaran IPS. Hal tersebut dapat dilihat dari hasil ulangan harian IPS yang pertama di kelas IX D MTs Negeri 3 Trenggalek pada materi mengembangkan ekonomi kreatif bedasarkan potensi wilayah mencapai rata-rata 57,8 dan hanya $50 \%$ siswa mencapai nilai 70 atau $>70$. Padahal idealnya minimal harus mencapai $100 \%$ siswa mendapat 70 atau $>70$. Kondisi tersebut disebabkan oleh kenyataan sehari-hari yang menunjukkan bahwa siswa kelihatannya jenuh mengikuti pelajaran IPS.

Pembelajaran sehari-hari menggunakan metode ceramah dan latihan-latihan soal secaraindividual Sdan tidak ada interaksi antar siswa yang pandai, sedang dan normal. Hal ini terbukti sebagian besar siswa mengeluh apabila diajak belajar IPS. Kenyataan tersebut, 
menunjukkan bahwa proses yang dilakukan oleh guru untuk pembelajaran IPS belum aktif. Dengan demikian dapat diduga bahwa yang menjadi kendala yang dirasakan adalah masalah proses pembelajaran yang kurang variasi dan kurang melibatkan siswa secara aktif. Guru menggunakan model pembelajaran yang terkesan monoton sehingga siswa menjadi kurang aktif. Melihat hal tersebut, maka perlu dilakukan suatu penelitian ilmiah, dengan tujuan untuk menemukan sebuah alternatif pemecahan masalah bagaimana cara penyajian dan suasana pembelajaran IPS yang cocok untuk siswa, dalam upaya meningkatkan kualitas pembelajaran IPS, agar dapat meningkatkan hasil belajar peserta didik. Salah satu solusinya yaitu dengan mengembangkan suatu pendekatan pembelajaran yang membuat peserta didik lebih aktif dan paham terhadap materi pelajaran. Model Pembelajaran Learning community sulit didefinisikan secara jelas karena masih baru dan bersifat kompleks (Pancucci, 2007). Tetapi menurut Zhao \& Kuh (2004), konsep learning community tidaklah baru sama sekali. Konsep ini diperkenalkan oleh Alexander Meikle john pada tahun 1920 (Smith dalam Zhao\&Kuh,2004).

Pengembangan selanjutnya juga dilakukan pada tahun 1960 dan 1980. Bielaczyc \& Collins (dalam Tastra et al., 2009) mengungkapkan bahwa komunitas belajar (learning communities) adalah suatu budaya belajar yang melibatkan setiap siswa untuk melakukan upaya-upaya kolektif dalam membangun pemahaman.Tiga ide pokok dalam profesional learning community meliputi: 1) memastikan bahwa siswa belajar, 2) menciptakan budaya kolaboratif dan 3) fokus pada hasil (DuFour dalam Huges, 2006). Menurut Lenning dan Ebbers (dalam Zhao \& Kuh, 2004), terdapat empat bentuk learning community. Salah satunya adalah learning community yang diterapkan dalam pembelajaran di kelas. Pada bentuk ini, Model Learning community sebagai lokus pembangunan komunitas yang dicirikan dengan teknikteknik pembelajaran kooperatif dan aktivitas pembelajaran proses kelompok sebagai sebuah pendekatan pendidikan yang terintegrasi. Sesuai dengan latar belakang dan tujuan penelitian, Model Learning community yang dimaksud pada penelitian ini adalah bentuk learning community yang diterapkan dalam pembelajaran dikelas.Secara lebih sfesifik, Markowitz, et al. (dalam Singh et al., 2009) mendefinisikan classroom learning communities sebagai sesuatu yang mendorong: (1) penghargaan terhadap perbedaan pelajar (budaya, bahasa, umur, dan sebagainya) dalam kelas; (2) kesediaan siswa untuk mengambil risiko intelektual dalam lingkungan belajar; (3) tujuan bersama untuk meningkatkan pengetahuan dan keterampilan secara berkesinambungan; dan (4) sebuah keterkaitan antara pelajar yang mengarah ke identitas umum dan rasa memiliki (sense of belonging). Karakteristik ini digunakan sebagai kerangka untuk mengembangkan strategi instruksional pengembangan learning community. Learning community dilandasi oleh konstruktivisme sosial (Cross dalam Zhao \& Kuh,2004).

Kontruktivisme sosial merupakan paradigma pembelajaran yang digagas oleh Vygotsky, pembelajaran berfokus pada proses dan interaksi dalam konteks sosial (Hung dalam Perry et al., 2009). Interaksi dan proses sosial mejadi perhatian dalam mencapai tujuan pembelajaran. Hal senada diungkapkan oleh Syamsuri dan Kennedy. MenurutSyamsuri (2007), learningcommunitymerupakan suatu konsep. terciptanya masyarakat belajar di sekolah, yakni proses belajar membelajarkan antara guru dengan guru, guru dengan siswa, siswa dengan siswa, dan bahkan antara masyarakat sekolah dengan masyarakat di luar sekolah, agar prestasi belajar siswa dapat ditingkatkan. Menurut Kennedy (2009), learning community berusaha menggeser pembelajaran yang bersifat individual menjadi pembelajaran yang bersifat sosial. Ini berarti iklim kompetitif dalam kelas harus diubah menjadi iklim sosial, sehingga tidak terjadi kesenjangan intelektual dan pengalaman di antara siswa. Kennedy (2009) juga mengungkapkan bahwa seorang guru dalam learning community lebih berperan untuk menawarkan pernyataan ulang, memberi klarifikasi, memberi contoh-contoh, memberikan ringkasan, memotivasi siswa untuk bekerja sebaik mungkin, serta menjadi pendengar yang aktif. Ini memberikan dasar bagaimana seharusnya guru memandang, memperlakukan, dan merespon siswa. Engstrom \& Tinto (2008) menunjukkan bahwa aspek dalam komunitas belajar (learning community) yang berkontribusi terhadap keberhasilan belajar adalah lingkungan yang aman dan mendukung proses pembelajaran. Lingkungan ini tercipta dengan 
menerapkan empat strategi kunci dalam menciptakan komunitas belajar. Empat strategi kunci itu meliputi (1) penggunaan strategi pembelajaran aktif dan kolaboratif, (2) pengembangan kurikulum yang koheren dan terpadu, (3) pengintegrasian layanan dan program satuan pendidikan dalam komunitas belajar, dan (4) pemberian dorongan dan dukungan kepada pebelajar untuk memiliki harapan yangtinggi.

Berdasarkan penelitian Engstrom \& Tinto, dapat diambil dua hal penting dalam mengembangkan Model Learning Community. Pertama, bahwa seting pembelajaran kolaboratif sangat penting digunakan dalam model ini. Kedua, peran guru sebagai motivator dalam menumbuhkan ekspektasi dan rasa percaya diri siswa yang menjadi ciri yang khas dalam Model Learning Community. Pembelajaran kolaboratif dan eksperensial merupakan kunci dari learning community (Gabelnick et al. dalam Kent, 2009).Saat ini pemerintah sudah sering mensosialisasikan berbagai model pembelajaran. Salah satu model pembelajaran yang disosialisasikan adalah model pembelajaran learning community. Learning community dilandasi oleh konstruktivisme sosial.

Kontruktivisme sosial merupakan paradigma pembelajaran yang digagas oleh Vygotsky, pembelajaran berfokus pada proses dan interaksi dalam konteks social. Interaksi dan proses sosial mejadi perhatian dalam mencapai tujuan pembelajaran. learning community merupakan suatu konsep terciptanya masyarakat belajar di sekolah, yakni proses belajar membelajarkan antara guru dengan guru, guru dengan siswa, siswa dengan siswa, dan bahkan antara masyarakat sekolah dengan masyarakat di luar sekolah, agar prestasi belajar siswa dapat ditingkatkan. learning community berusaha menggeser pembelajaran yang bersifat individual menjadi pembelajaran yang bersifat sosial. Ini berarti iklim kompetitif dalam kelas harus diubah menjadi iklim sosial, sehingga tidak terjadi kesenjangan intelektual dan pengalaman di antara siswa. Berdasarkan pemikiran dan permasalahan tersebut diatas maka penelit iingin menerapkannya apakah ada pengaruh penggunaan model pembelajaran kooperatif dengan pendekatan struktur terhadap keaktifan peserta didik untuk mencapai hasil belajar pada mata pelajaran Ekonomi. Oleh karena itu, penulis tertarik untuk mengadakan penelitian dengan judul: "Upaya Peningkatan Prestasi Belajar Ips Melalui Pendekatan Learning Community Materi Mengembangkan Ekonomi Kreatif Bedasarkan Potensi Wilayah Pada Siswa Kelas IX D Mts Negeri 3 Trenggalek Tahun Pelajaran 2019/2020”.

\section{METODE PENELITIAN}

Penelitian ini menggunakan rancangan Penelitian Tindakan Kelas (PTK). PTK adalah penelitian yang dilakukan oleh guru di dalam kelasnya sendiri melalui refleksi diri, dengan tujuan untuk memperbaiki kinerjanya sebagai guru, sehingga hasil belajar siswa menjadi meningkat (Wardani, 2005). Penelitian Tindakan Kelas sebagaimana dinyatakan oleh Kemmis dan Mc Taggart (dalam Yatim Riyanto, 2001) merupakan penelitian yang bersiklus, yang terdiri dari perencanaan,pelaksanaan,observasi, dan refleksi yang dilakukan secara berulang, hal ini dapat digambarkan sebagai berikut: (1) ObyekTindakanProses penelitian tindakan kelas ditik beratkan pada prestasi belajar siswa dalam proses pembelajaran melalui pendekatan learning community, melalui strategi inidiharapkan dapat meningkatkan kemampuan siswa dalam meraih prestasi belajar(2) Tempat, waktu dan subyekpenelitian.

Penelitian dilaksanakan di MTs Negeri 3 Trenggalek KecamatanMujungan, Kabupaten TrenggalekPenelitian dilaksanakan selama 3 bulan mulai dari minggu ke 2 bulan Juli 2019sampai denganminggu ke 2 bulan September 2019. Subyek penelitian adalah siswa kelas IX D MTs Negeri 3 Trenggalek dengan jumlah siswa di kelas ini adalah 25 orang yang terdiri dari 13 orang laki-laki dan 12 orang perempuan. (3) SumberDataSumber data penelitian adalah data primer yang diperoleh melalui angket, wawancara dan observasi pada siswa kelas IX D MTs Negeri 3 Trenggalek pada tahun ajaran 2019/2020. (4) Teknik dan alat pengumpulandata. Dalam PTK ini pengumpulan data dilakukan dengan teknik: (a) Angket, yaitu untuk memperoleh data secara cepat dari responden dalam waktu singkat. (b) Observasi, yaitu untuk cross check data yang dikumpulkan dari angket, tentang sikap dan perilaku guru selama 
kegiatan sehingga diharapkan mendapatkan data yangakurat. (d) Wawancara, yaitu melengkapi data yang diperoleh melalui angket dan observasi. (4) ValidasiData. Untuk memperoleh data yang valid peneliti melalukan validasi data yang diperoleh dari angket, observasi dan wawancara. (5) Analisisdata Analisis data yang dipergunakan dalam penelitian ini adalah : (a) Analisis kuantitatif, yaitu adalah analisis data yang dinyatakan denganangka. (b) Analisis kualitatif adalah analisis data yang dinyatakan dengan. kualita atau keterangan yang dilakukan padadatahasil angket,observasi, danwawancara.Analisis digunakan terhadap data hasil penelitian tahap pra siklus, sikluspertama, dan siklus ke dua. Teknik analisis dilakukan denganmembandingkan seberapa besar selisih nilaiyang diperoleh siswa dalam mengikuti ulangan harian dan aktifitas siswa selama proses pembelajaran pada setiap tahap.

\section{HASIL PENELITIAN DAN PEMBAHASAN}

Deskripsi KondisiAwal. (1) Deskripsi Hasil Belajar Prasiklus.Hasil pembelajaran kondisi awal IPS mengembangkan ekonomi kreatif bedasarkan potensi wilayah melalui pendekatan learning community diperoleh data dimana pada masa pra siklus mencapai ratarata 63,33 dan hanya $50 \%$ siswa mencapai nilai 70 atau $>70$. Padahal idealnya minimal harus mencapai 100\% siswa mendapat 70 atau > 70. (2) Deskripsi Prosespembelajaran. Proses pembelajaran kondisi awal siswa kelas IX D MTs Negeri 3 Trenggalek pada mata pelajaran IPS Mengembangkan Ekonomi Kreatif Bedasarkan Potensi Wilayah kurang berhasil karena rata-rata kelas mencapai 63,33 dan hanya 50\% siswa mencapai ketuntasan atau nilainya lebih dari 70. Padahal idealnya ketuntasan klasikal adalah 85\% dan KKM harus 70.

\section{Deskripsi Hasil Siklus I :}

1) PerencanaanTindakan. Pelaksanaan pembelajaran Penelitian Tindakan Kelas (PTK) siklus I dilaksanakan dalam tiga kali pertemuan. Pertemuan pertama dilaksanakan tanggal 23 Sepember2019, pertemuan kedua tanggal 25Sepember 2019 danpertemuanketiga tanggal 30 Sepember 2019.Sebelummelaksanakan tindakan pembelajaran, dilakukan persiapan terakhir. Langkah awal dalam perencanaan adalah peneliti memeriksa Rencana Pelaksanaan Pembelajaran (RPP) yang telah disusun, dibaca ulang, mencermati setiap butir yang akan direncanakan. Peneliti memeriksa skenario pembelajaran yang terdapat dalamRPP yang akan diimplementasikan melalui kegiatan pembelajaran dari kegiatan awal sampai kegiatanakhir. (a) Kegiatan Awal. Pertemuan pertama dilaksanakan tanggal 23 Sepember 2019. Kegiatan awal dilaksanakan kurang lebih 10 menit, yaitu memberikan salam, memeriksa kehadiran siswa, mengkondisikan siswa agar siap menerima pelajaran, memotivasi siswa, memberikan apersepsi untuk memusatkan perhatian siswa pada materi pembelajaran.Peneliti menyampaikan materi dan tujuan pembelajaran yangakan dilaksanakan. (b) KegiatanInti. Kegiatan inti siklus I pertemuan pertama dilaksanakan selama 40 menit. Guru membentuk kelompok diskusi berdasarkanlokasi tempat duduk siswa, untuk melaksanakan diskusi sesuai permaslahan yang ada.Ketua kelompok mengambil lembar kerja siswa yang telah disiapkan untuk di diskusikan secara bersamasama di dalam kelompok. Guru mengawasi siswa yang sedang melakukan diskusi. Setelah kerja kelompok selesai, dilanjutkan dengan diskusi kelas untuk saling mencocokkan hasil kerjanya. Setiap kelompok diberi kesempatan untuk menyampaikan hasil diskusi dan kelompok lain memberikan tanggapan.Setelah semua kelompok selesai presentasi, guru mengulas materi dan hasil kerja siswa. Dengan bimbingan guru, siswa membuat kesimpulan dari kegiatan yang telah dilaksanakan. (c) KegiatanAkhir. Guru memberikan saran dan tindak lanjut untuk pelajaran berikutnya. Guru memberi tugas pekerjaan rumah pada siswa untuk menyelasaikan yang akan dibahas pada pertemuan selanjutnya.

Pelaksanaan Tindakan Siswa dengan bimbingan guru mengkaji dan menelaah masalah yang ada pada materi tentang mengembangkan ekonomi kreatif bedasarkan potensi wilayah kemudian dilanjutkan dengan menjawab pertanyaan pada lembar kerja siswa. Siswa mengerjakan LKS, beberapa siswa melaporkan hasil kerjanya di depan kelas bergantian dan siswa lain yang belum maju memberikan tanggapan, sanggahan, 
pertanyaan dan pendapat yang berbeda kepada siswa yang sedang melaporkan hasilkerjanya.Selama kegiatan pembelajaran yang berlangsung selama 3 kali pertemuan, semua kegiatan berjalan lancar dan tidak ada kendala yang menganggu proses belajar mengajar.

(3) Hasil Pengamatan (a) Hasil Belajar. Hasil belajar pada siklus I terdapat kenaikan prestasi belajar berupa rata- rata kelas menjadi 69,60 dan sebanyak $64 \%$ siswa memperoleh nilai tuntas. Nilai terendah adalah 50 dan nilai tertinggi adalah 90. (b) Proses Pembelajaran. Dalam pembelajaran IPS siswa mulai tertarik untuk mengikuti diskusi walaupun masih ada yang bermain-main, pasif dalam diskusi. Dengan model pembelajaran learning community mulai ada perubahan prestasi belajar siswa ke arah peningkatan. (c) Refleksi. Dengan memperhatikan hasil pengamatan terhadap siswa diperoleh hal-hal sebagai berikut: (i) Dalam proses pembelajaran IPS di kelas IX D terdapat peningkatan prestasi belajar dari nilai rata-rata 63,33 menjadi 69,60 dan jumlah siswa yang tuntas dari $50 \%$ menjadi $75 \%$.(ii) Tetap meningkatkan prestasi belajar siswa dengan menggunakan model pembelajaran learning community.

\section{Deskripsi Hasil Siklus II :}

PerencanaanTindakan. Pelaksanaan kegiatan dilaksanakan pada tanggal 7,9 dan 14Oktober 2019 Sebelum melaksanakan tindakan perbaikan, dilakukan persiapan terakhir. Langkah awal dalamperencanaan adalah peneliti memeriksa RPP yang telah disusun, dibaca ulang, mencermati setiap butirnya.Yang tidak kalah pentingnya adalah semua perencanaan harus dimatangkan dan saran prasarana dipersiapkan dengan baik agar kegiatan PBM tidak menemukan hambatan yang dapat menganggu proses penyusunan PTK ini.(a) KegiatanAwal. Kegiatan awaldilaksanakan kurang lebih 10 menit, yaitumemberikan salam, memeriksa kehadiran siswa, mengkondisikan siswa agar siap menerima pelajaran, memotivasi siswa, memberikan apersepsi untuk memusatkan perhatian siswa pada materi pembelajaran.Peneliti menyampaikan materi dan tujuan pembelajaran yang akandilaksanakan.(b) KegiatanInti. Kegiatan inti siklus II pertemuan pertama dilaksanakan selama 40 menit. Guru membentuk kelompok diskusi berdasarkan lokasi tempat duduk siswa, untuk melaksanakan diskusi sesuai permaslahan yang ada. Ketua kelompok mengambil lembar kerja siswa yang telah disiapkan untuk di diskusikan secara bersama-sama di dalam kelompok.Guru mengawasi siswa yang sedang melakukan diskusi. Setelah kerja kelompok selesai, dilanjutkan dengan diskusi kelas untuk saling mencocokkan hasil kerjanya. Setiap kelompok diberi kesempatan untuk menyampaikan hasil diskusi dan kelompok lain memberikan tanggapan. Setelah semua kelompok selesai presentasi, guru mengulas materi dan hasil kerja siswa. Denganbimbingan guru, siswa membuat kesimpulan dari kegiatanyangtelahdilaksanakan. Kegiatan Akhir. Guru memberikan saran dan tindak lanjut untuk pelajaran berikutnya Guru memberi tugas pekerjaan rumah pada siswa untuk menyelasaikan yang akan dibahas pada pertemuan selanjutnya.

1) Pelaksanaan Tindakan. Siswa dengan bimbingan guru mengkaji dan menelaah masalah yang ada pada materi tentang mengembangkan ekonomi kreatif bedasarkan potensi wilayah, kemudian dilanjutkan dengan menjawab pertanyaan pada lembar kerja siswa.Siswa mengerjakan LKS, beberapa siswa melaporkan hasil kerjanya di depan kelas bergantian dan siswa lain yang belum maju memberikan tanggapan, sanggahan, pertanyaan dan pendapat yang berbeda kepada siswa yang sedang melaporkan hasil kerjanya. Selama kegiatan pembelajaran yang berlangsungselama3 kali pertemuan, semua kegiatan berjalan lancar dan tidak ada kendala yang menganggu proses belajar mengajar. Hasil Pengamatan (a) Hasil Belajar. Hasil belajar pada siklus II terdapat kenaikan prestasi belajar berupa rata- rata kelas menjadi 78,80 dan sebanyak $90 \%$ siswa memperoleh nilai tuntas. Nilai terendah adalah 65 dan nilai tertinggi adalah 90 (b) Proses Pembelajaran. Dalam pembelajaran IPS siswa sangat tertarik untuk mengikuti diskusi, siswa yang suka bermainmain tidak ada, siswa sangat aktif dalam diskusi. Dengan model pembelajaran learning community 
perubahan prestasi belajar siswa kea rah peningkatan sangat dirasakan. (c) RefleksiDengan memperhatikan hasil pengamatan terhadapsiswa diperoleh hal-hal sebagai berikut: (i) Dalam proses pembelajaran IPSdi kelas IX D: terdapat peningkatan prestasi belajar dari nilai rata- rata 69,60 menjadi 78,80 dan jumlah siswa yang tuntas dari $64 \%$ menjadi88\%. (ii) Tetap meningkatkan prestasi belajar siswa dengan menggunakan model pembelajaran learningcommunity.

\section{KESIMPULAN}

1) Hasil pembelajaran kondisi awal IPS pada materi mengembangkan ekonomi kreatif bedasarkan potensi wilayah melalui pendekatan learning community diperoleh data dimana pada masa prasiklus mencapai rata-rata 63,33 dan hanya $50 \%$ siswa mencapai nilai 70 atau $>70$. Padahal idealnya minimal harus mencapai $100 \%$ siswa mendapat 70 atau $>70$.

2) Hasil belajar pada siklus I terdapat kenaikan prestasi belajar berupa rata-rata kelas menjadi 69,60 dan sebanyak $64 \%$ siswa memperoleh nilai tuntas. Nilai terendah adalah 50 dan nilai tertinggi adalah90. (3) Hasil belajar pada siklus II terdapat kenaikan prestasi belajar berupa rata-rata kelas menjadi 78,80 dan sebanyak $88 \%$ siswa memperoleh nilai tuntas. Nilai terendah adalah 65 dan nilai tertinggi adalah 90. Karena dalam penelitian ini terjadi peningkatan prestasi belajar siswa, maka peneliti berkesimpulan bahwa model pembelajaran learning community sangat cocok digunakan dalam pembelajaran IPS.

\section{DAFTAR PUSTAKA}

Arikunto, Suharsimi, Suhardjono, Supardi. 2006. Penelitian Tindakan Kelas. Jakarta: PT Bumi Aksara.

Chun-Mei Zhao and George D. Kuh. (2004). Adding Value: Learning Communities and Student Engagement. Research in Higher Education, 5(2): 115-138.

Hisyam Zaini, Bermawy Munthe, Sekar Ayu Aryani. 2004. Strategi Pembelajaran Aktif. Yogyakarta: CTSD.

Huges, J. (2006). But it's not a proper blog, is it? Tangled weblogs as spaces for transformational stories of learning and teaching. In the proceedings of First Annual Blended Learning Conference: Blended learning: $p$

Kennedy, Anne, Deuel, Angie, Nelson, Tamara Holmlund, \& Slavit, David. (2011). Distributed leadership in professional learning communities. Phi Delta Kappan, 92(8): 20-24

Mulyasa, E.. 2005. Menjadi Guru Profesional, Menciptakan Pembelajaran Kreatif dan Menyenangkan. Bandung: PT Remaja Rosdakarya Offset

Nana Sudjana. 2008. Penilaian Hasil Proses BelajarM engajar. Bandung: PT. Remaja Rosdakarya.

Pancucci, S. (2007). Train the trainer. The bricks in the learning community scaffold of professional development. International Journal of Social Sciences, 5(8): 34-43.

Saiful Rachman, Yoto, Syarif Suhartadi, Suparti. 2006. Penelitian Tindakan Kelas dan Penulisan Karya Ilmiah. Surabaya: SIC Bekerjasama Dengan Dinas P dan K Provinsi Jawa Timur.

Silberman,Melvin.2006.AktiveLearning101CaraBelajarSiswaAktif.Bandung: Nusamedia.

Suiyanto. 2007. Modul PLPG Model Model Pembelajaran Inovatif. Surakarta:Panitia Sertifikasi Guru Rayon 13.

Sumadi. 2002. Prestasi dalam Belajar. Pustaka Widyamara : Jakarta

Slameto. 2001. Evaluasi Pendidikan. Jakarta: PT. Bumi Aksara.

Syamsuri I. (2007). Membangun Learning Community menuju sekolah berprestasi, Apa dan mengapa Lesson Study. Bandung.

Trianto. 2007. Model-model Pembelajaran Inovatif Berorientasi Konstruktivistik. Jakarta: Perpustakaan Nasional KDT. 